\title{
Persistent Pollutants in the White-tailed Eagle (Haliaeetus albicilla) in the Federal Republic of Germany
}

\author{
J. H. Koeman, Ph.D. (Utrecht), R. H. HaddeRINGH, M.Sc. (Utrecht) \\ \& M. F. I. J. BiJleVeld, M.Sc. (Amsterdam) \\ World Wildlife Fund, PO Box 168, 1110 Morges, Switzerland
}

Institute of Veterinary Pharmacology and Toxicology, University of Utrecht, Biltstraat 172, Utrecht, The Netherlands,

\section{ABSTRACT}

A study was made of the possible relationship between persistent pollutants and the decline in reproductive success of the White-tailed Eagle (Haliaeetus albicilla) in Schleswig Holstein, Federal Republic of Germany. Chemical analyses were made of Eagle's eggs, of one adult Eagle which was found dead, and of specimens of several species of predatory animals and of two Sparrow Hawks which were also found dead. The conclusion is that it is very probable that DDE could be the main factor responsible for the decline of reproductive success of the White-tailed Eagle in Schleswig Holstein.

\section{INTRODUCTION}

The State of Schleswig Holstein in the Federal Republic of Germany contains one of the last strongholds of the White-tailed or Sea Eagle (Haliaeetus albicilla) on the European continent outside Scandinavia. After being exterminated as a breeding species by uncontrolled hunting at the end of the 19th century (e.g. Hagen, 1913), the White-tailed Eagle reestablished a small breeding population in Schleswig Holstein after World War II. Eight potential Eagle biotopes are available in Schleswig Holstein today, of which four or five were occupied in the period from 1968 to 1971 . Figure 1 shows one of the nests-a huge structure about 2 metres high.

Reproductive success of the population has dropped markedly during the last ten years, and, in 1969, 1970 , and 1971 , only one young bird was reared each year.

Alarmed by the poor breeding results, Dr Heinz Brüll, Director of the Biological Research Station at Hartenholm in Schleswig Holstein, suspected that persistent poisons were responsible for the lack of breeding success, as no other known factor could account for the observed change in reproduction. Because of previous experience in this field, the Institute of Veterinary Pharmacology and Toxicology at Utrecht became involved in a field survey and laboratory study to measure the degree of contamination of Eagle eggs and prey animals. Financial support was obtained from the Organization for Applied Sciences (TNO) of the Netherlands and the World Wildlife Fund. The mercury analyses were carried out in collaboration with the Interuniversitair Reactor Institute at Delft, the Netherlands.

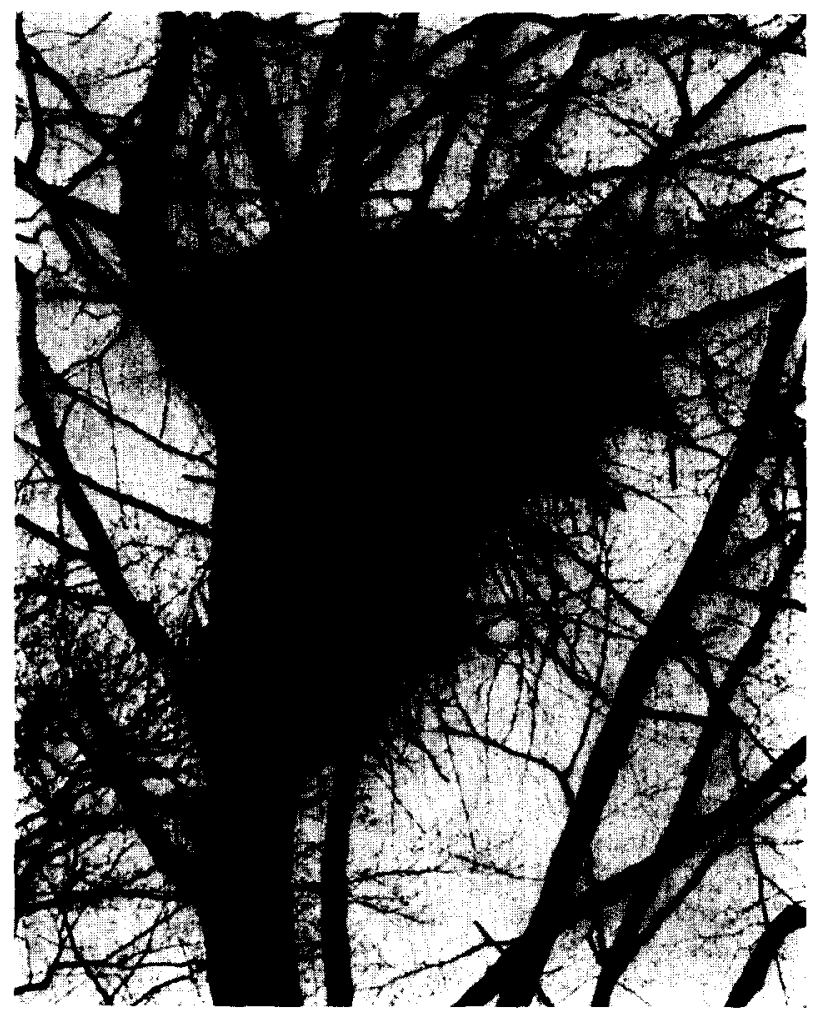

Fig. 1. A White-tailed Eagle's eyrie in a large Beech (Fagus sylvatica) tree in Schleswig Holstein, West Germany. The nest is about $2 \mathrm{~m}$ in height. Photo: J. L. M. Bos/WWF.

\section{METHODS}

In 1969 two Eagle eggs and one adult Eagle, which was found dead, became available for chemical analysis. In the spring of 1970 , prey animals were 73

Biological Conservation, Vol. 4, No. 5, October 1972-@ Applied Science Publishers Ltd, England-Printed in Great Britain 
collected in collaboration with the Biological Research Station at Hartenholm, the main species involved being Coot (Fulica atra) and Pike (Esox lucius). In one of the biotopes, Great-crested Grebes (Podiceps cristatus) were shot, while three Eagle eggs were available for analysis in that year. In addition, analyses were made of two Sparrow Hawks (Accipiter nisus) which were found dead in Schleswig Holstein. In 1971, six Grebes were collected and four Eagle eggs were found of which three were submitted to chemical analysis.

Of most of the prey animals collected, total body analyses were carried out. The beaks, feathers, and legs, were removed prior to homogenization of the birds. After homogenization, two 5-10 gm aliquots were taken for pesticide and metal analysis. Eggs were analyzed individually, the total contents of the eggs being homogenized and again two aliquots being taken for analysis.

For the chlorinated hydrocarbon analyses, amounts of 3-5 gm of the homogenized material were ground with anhydrous sodium sulphate and extracted for six hours with petroleum ether in a Soxhlet apparatus. Extracts were concentrated, taken up in hexane, and partitioned with DMF (dimethyl-formamide) according to the instructions of Maunder et al. (1964). The hexane fraction thus obtained was concentrated, and the chlorinated hydrocarbons were eluted on a partially inactivated Florisil column-first with hexane and thereafter with 10 per cent diethylether in hexane.
Livers of Grebes and Eagle eggs collected in 1971 were submitted to the clean-up procedure devised by Holden \& Marsden (1969).

The fractions obtained after column separation were then analysed by electron-capture gas chromatography for which purpose a Varian Aerograph 204-1B instrument was used (column DC 200(10 per cent) on Gaschrom Q 80/100 mesh). The results of the egg analyses were confirmed by thin-layer chromatography according to the method devised by Kovacs (1963).

Total mercury analyses were carried out by neutronactivation analysis in the Interuniversitair Reactor Institute at Delft, the Netherlands.

\section{RESULTS AND DISCUSSION}

The results of the analyses of Eagle eggs, of one adult Eagle, and of two Sparrow Hawks, are given in Table I. The results of the prey analyses are presented in Table II.

Chemicals detected included mercury, DDE, PCBS (polychlorinated diphenyls), hexachlorobenzene, Dieldrin, and heptachlorepoxide. On average, the residue levels are lowest for hexachlorobenzene, heptachlorepoxide, and Dieldrin. In two of the three prey species investigated, Dieldrin could not be detected, while heptachlorepoxide was found only in the tissues of the Sparrow Hawks.

TABLE I

Residue Levels of Chlorinated Hydrocarbon Compounds and Mercury in Eggs of White-tailed Eagles, One Adult Eagle, and Two Sparrow Hawks

\begin{tabular}{|c|c|c|c|c|c|c|c|}
\hline Specimen & $\begin{array}{l}\text { No. of } \\
\text { biotope }\end{array}$ & Year & DDE & PCBs* & 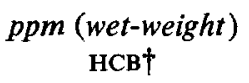 & Dieldrin & $H g$ \\
\hline Eagle egg (embryonated) & 1 & 1969 & $1 \cdot 2$ & 79 & $3 \cdot 5$ & $0 \cdot 50$ & $0 \cdot 16$ \\
\hline Eagle egg (embryonated) & 4 & 1969 & 17 & 97 & $1 \cdot 1$ & $0 \cdot 40$ & $2 \cdot 1$ \\
\hline Eagle egg (embryonated) & 2 & 1970 & 11 & $8 \cdot 2$ & $0 \cdot 30$ & $0 \cdot 11$ & 0.42 \\
\hline Eagle egg (embryonated) & 3 & 1970 & 17 & 25 & 0.83 & $0 \cdot 19$ & 0.23 \\
\hline Eagle egg (embryonated) & 5 & 1970 & $4 \cdot 5$ & 19 & 0.80 & $0 \cdot 11$ & 0.24 \\
\hline $\begin{array}{l}\text { Eagle egg } \\
\text { (sterile) }\end{array}$ & 3 & 1971 & 12 & 12 & - & 0.27 & 0.39 \\
\hline $\begin{array}{r}\text { Eagle egg } \\
\text { (sterile) }\end{array}$ & 3 & 1971 & 13 & 12 & - & 0.25 & 0.37 \\
\hline Eagle egg (embryonated) & 1 & 1971 & $5 \cdot 3$ & $6 \cdot 1$ & - & 0.16 & $0 \cdot 16$ \\
\hline $\begin{array}{l}\text { Adult Eagle } q \text { found } \\
\text { dead }\end{array}$ & - & $\begin{array}{r}1969\left(\mathrm{~L}^{* *}\right) \\
\left(\mathrm{K}^{* *}\right)\end{array}$ & 4 & 35 & $0 \cdot 36$ & 0.25 & $\begin{array}{l}48 \cdot 2 \\
26 \cdot 5\end{array}$ \\
\hline Sparrow Hawk ơł & - & $1970\left(B^{* *}\right)$ & 46 & 77 & $1 \cdot 0$ & 0.29 & $1 \cdot 4$ \\
\hline Sparrow Hawk o $\ddagger$ & - & $1970\left(B^{* *}\right)$ & 77 & 25 & $3 \cdot 8$ & 0.33 & 0.68 \\
\hline
\end{tabular}

${ }^{*}$ PCBS $=$ polychlorinated biphenyls.

$\dagger$ HCB $=$ hexachlorobenzene.

** $\mathrm{L}=$ liver; $\mathrm{K}=$ kidney; $\mathrm{B}=$ brain.

$¥$ In the brains of the Sparrow Hawks heptachlorepoxide was detected $-0.26 \mathrm{ppm}$ in the male and $0.59 \mathrm{ppm}$ in the female. 
TABLE II

Residue Levels of Chlorinated Hydrocarbon Compounds and Mercury in Tissues of Coots, Pike, and Great-crested Grebes

(collected in 1970 unless otherwise indicated)

\begin{tabular}{|c|c|c|c|c|c|c|c|}
\hline \multirow{2}{*}{$\begin{array}{l}\text { No. of } \\
\text { biotope }\end{array}$} & \multirow{2}{*}{$\begin{array}{l}\text { No. of } \\
\text { specs }\end{array}$} & \multirow{2}{*}{ Tissues* } & \multicolumn{5}{|c|}{ ppm (wet-weight) mean and range } \\
\hline & & & DDE & PCBS & $\mathrm{HCB}$ & Dieldrin & $\mathrm{Hg}$ \\
\hline \multicolumn{8}{|c|}{ Coot (Fulica atra) } \\
\hline 1 & 2 & $\mathbf{T}$ & $\begin{array}{c}0 \cdot 37 \\
(0 \cdot 20-0.54)\end{array}$ & $\begin{array}{c}1 \cdot 7 \\
(1 \cdot 1-2 \cdot 3)\end{array}$ & $\begin{array}{c}0.043 \\
(0.043-0.043)\end{array}$ & {$[?<0 \cdot 01]$} & $\begin{array}{c}0.27 \\
(0.11-0.43)\end{array}$ \\
\hline 2 & 5 & $\mathbf{T}$ & $\begin{array}{c}0 \cdot 12 \\
(0 \cdot 061-0 \cdot 25)\end{array}$ & $\begin{array}{c}1 \cdot 8 \\
(0 \cdot 35-4 \cdot 6)\end{array}$ & $\begin{array}{c}0.032 \\
(0.006-0.081)\end{array}$ & {$[?<0.03]$} & $\begin{array}{c}0.12 \\
(0.087-0 \cdot 18)\end{array}$ \\
\hline 3 & 4 & $\mathbf{T}$ & $\begin{array}{c}0.069 \\
(0 \cdot 043-0 \cdot 11)\end{array}$ & $\begin{array}{c}0 \cdot 52 \\
(0 \cdot 27-1 \cdot 1)\end{array}$ & $\begin{array}{c}0.008 \\
(0.002-0.013)\end{array}$ & {$[?<0.03]$} & $\begin{array}{c}0.081 \\
(0.063-0 \cdot 11)\end{array}$ \\
\hline 5 & 5 & $\mathrm{~T}$ & $\begin{array}{c}0 \cdot 33 \\
(0 \cdot 045-0 \cdot 76)\end{array}$ & $\begin{array}{c}2 \cdot 4 \\
(0 \cdot 35-6 \cdot 3)\end{array}$ & $\begin{array}{c}0.13 \\
(0.017-0.29)\end{array}$ & {$[?<0 \cdot 03]$} & $\begin{array}{c}0.076 \\
(0.033-0.13)\end{array}$ \\
\hline \multicolumn{8}{|c|}{ Pike (Esox lucius) } \\
\hline 1 & 3 & $\mathrm{~T}$ & $\begin{array}{c}\mathbf{0} \cdot 17 \\
(0 \cdot 16-0 \cdot 18)\end{array}$ & $\begin{array}{c}0.94 \\
(0.80-1 \cdot 1)\end{array}$ & $\begin{array}{c}0.021 \\
(0.019-0.024)\end{array}$ & {$[?<0.005]$} & $\begin{array}{c}0.42 \\
(0.26-0.51)\end{array}$ \\
\hline 2 & 7 & $\mathrm{~T}$ & $\begin{array}{c}0 \cdot 12 \\
(0 \cdot 039-0 \cdot 35)\end{array}$ & $\begin{array}{c}0 \cdot 72 \\
(0 \cdot 16-1 \cdot 9)\end{array}$ & $\begin{array}{c}0 \cdot 18 \\
(0 \cdot 007-1 \cdot 2)\end{array}$ & {$[?<0 \cdot 02]$} & $\begin{array}{c}0 \cdot 24 \\
(0 \cdot 12-0 \cdot 63)\end{array}$ \\
\hline 4 & 5 & $\mathrm{~T}$ & n.a. $\dagger$ & n.a. & n.a. & n.a. & $\begin{array}{c}0.28 \\
(0 \cdot 19-0 \cdot 39)\end{array}$ \\
\hline \multicolumn{8}{|c|}{$\begin{array}{l}\text { Great-crested Grebe } \\
\text { (Podiceps cristatus) }\end{array}$} \\
\hline $1(197$ & 1) 6 & $\mathbf{L}$ & $\begin{array}{c}1 \cdot 3 \\
(0 \cdot 15-3 \cdot 0)\end{array}$ & $\begin{array}{c}11 \\
(3 \cdot 0-20)\end{array}$ & $\begin{array}{c}0.08 \\
(0.01-0 \cdot 23)\end{array}$ & {$[?<0.02-0.033]$} & n.a. \\
\hline 2 & 2 & $\mathrm{~T}$ & $\begin{array}{c}3 \cdot 7 \\
(2 \cdot 5-4 \cdot 9)\end{array}$ & $\begin{array}{c}32 \\
(30-33)\end{array}$ & $\begin{array}{c}0.66 \\
(0.45-0.87)\end{array}$ & $\begin{array}{c}0 \cdot 14 \\
(0 \cdot 015-0 \cdot 23)\end{array}$ & $\begin{array}{c}2 \cdot 1 \\
(2 \cdot 0-2 \cdot 1)\end{array}$ \\
\hline
\end{tabular}

${ }^{*} \mathrm{~T}=$ total body analysis; $\mathrm{L}=$ liver analysis.

$\dagger$ n.a. $=$ not analysed.

The levels found in Eagle eggs and in tissues of the Grebes and Sparrow Hawks are commonly of the order of from 10 to 100 times higher as regards DDE and PCBs than those in Coots and Pike. The levels of mercury in Eagle eggs are, on the average, of the same order as those found in Pike and as the higher levels among the Coots. Generally speaking, the levels found in Coots are very similar to those in Pike.

A very high mercury concentration was detected in the adult Eagle which was found dead in 1969.48.2 ppm was found in the liver and $26.5 \mathrm{ppm}$ in the kidneys. This level comes within the range of mercury concentrations found in tissues of birds of prey that had been poisoned with methyl-mercury compounds under experimental conditions (Borg et al., 1970; Koeman et al., 1971). It seems likely, therefore, that this bird died from mercury poisoning. Henriksson et al. (1966) reported high levels of mercury in the tissues of White-tailed Eagles which were found dead in Finland in 1965 and 1966. In six birds the liver contents varied from 4.6 to $27.1 \mathrm{ppm}$, while in four birds the levels in the kidneys ranged from $48 \cdot 6$ to $123.1 \mathrm{ppm}$.

High DDE and PCB concentrations were found in the brains of the Sparrow Hawks. Both birds were found dead and did not show any sign of what could be held responsible for their deaths. At present no information exists as to the range of concentrations of these compounds which may cause death in birds of prey. In experiments carried out with male Cowbirds (Molothrus ater), residues of DDE in the brain at death were estimated to be $314 \mathrm{ppm}$ or higher in 95 per cent of the cases (Stickel et al., 1970). In experiments with chickens (Gallus gallus), Vos \& Koeman (1970) found that PCB levels in the brain at death varied from 70 to $700 \mathrm{ppm}$. On these grounds it cannot be excluded that at least one of the Sparrow Hawks may have died from PCB poisoning.

As can be seen in Table I, most of the Eagle eggs tested were embryonated. There were no indications that the deaths of the embryos were due to the abandonment of the nest by the parent birds. In recent years the eyries have been well protected and continuously guarded during the breeding period. In a number of cases it was seen that breeding was extended after the normal breeding period. Thus, despite Fig. 2, it seems very probable that some other factor than abandonment is responsible for the lack of breeding success in the White-tailed Eagle. Indeed, there is a 
strong suspicion that DDE, particularly, can be involved in a decrease in reproduction of birds. Heath et al. (1969) found that DDE fed to Mallard (Anas platyrhynchos) in concentrations of 10 and $40 \mathrm{ppm}$ in the diet severely impaired reproductive success. It was concluded that the success of embryonated DDE-fed eggs was only one-third to one-half that of the control eggs, and duckling production was reduced by as much as 75 per cent. The eggshells

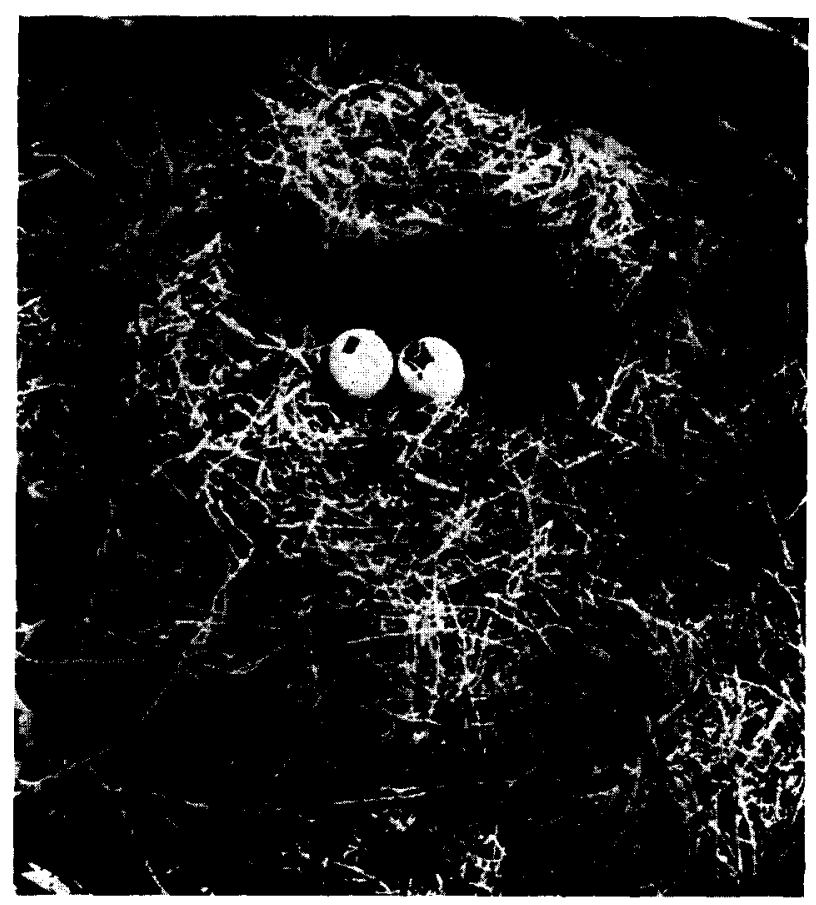

Fig. 2. Deserted White-tailed Eagle's nest in Schleswig Holstein, 1971. The large eggs have had holes pecked in them by crows and were found to contain DDE. Photo: S. Cats/ $W W F$.

appeared to be 13 per cent thinner than normal, shell fractures being observed that varied from hairline cracks to obvious breaks. It was found, however, that embryo mortality in eggs with uncracked shells was also 30-50 per cent higher than expected.

Comparable results were obtained in experiments carried out with captive Black Ducks (Anas rubripes) and DDE by Longcore et al. (1971). At levels of 10 and $30 \mathrm{ppm}$ in the food (dry-weight basis), the survival of 21-day ducklings of embryonated eggs was 40-76 per cent lower than survival of ducklings from undosed parents. These results show clearly that embryo mortality can be considered as a characteristic effect of DDE in the birds concerned, and give strong support to the hypothesis that, in the case of the German White-tailed Eagles, also, DDE could be the major cause of the lack of reproductive success. Detailed measurements of the thickness of the Eagle eggshells were not carried out, though it may be mentioned that they were not noticeably fragile.

A related species, the Bald Eagle (Haliaeetus leucocephalus, the American national bird), has also been showing a severe decline in the United States for rather many years (Sprunt, 1963). Although adult mortality caused by shooting may be responsible for part of the decline (Coon et al., 1970), in many areas a reduction of reproductive success has also been observed. Krantz et al. (1970) made a comparison of the pesticide levels in Bald Eagle eggs in relation to the rate of reproduction in various parts of the United States. DDE levels appeared to be highest in Maine, an area where nesting success is very poor. The average levels found in Bald Eagles were $4.76 \mathrm{ppm}$ in Wisconsin, $10.72 \mathrm{ppm}$ in Florida, and $21.76 \mathrm{ppm}$ in Maine. Because of this circumstantial evidence and the experimental data quoted above, it seems highly probable that DDE is involved in the decrease of reproduction in this species in certain areas in the United States. In the German White-tailed Eagles, the average level of DDE in the eggs is $10 \cdot 12 \mathrm{ppm}$. This is about equal to the level found in Bald Eagles in Florida, which were still producing young at a rate of 0.9 young per nest, which would imply that the White-tailed Eagle is slightly more susceptible than its generic relative in the United States.

Investigations that have been carried out so far do not, in general, support the hypothesis that PCBs are also involved in thin eggshells and reduction of reproduction in birds. In experiments with Mallards, Heath et al. (1970) fed PCBs (Aroclor 1254) at a level of 25 ppm for eleven weeks but found that this did not result in impaired reproduction and thinner eggshells. Similar results were obtained with Bobwhite (Colinus virginianus), which received a $50 \mathrm{ppm}$ concentration of Aroclor 1254 in their diet for one to three months. In experiments with Ring Doves (Streptopelia risoria), Peakall (1971) did not observe an effect on the eggshells when $10 \mathrm{ppm}$ of Aroclor 1254 was administered to the diet of the birds for six months. Only in one study with White Leghorn chickens (Gallus gallus), carried out by the Industrial Bio-Test Laboratories, Inc., in the United States (cited by Heath et al., 1970), were reduced egg-production and hatchability as well as thin eggshells observed after treatment of the birds with Aroclor 1242 at 10 and $100 \mathrm{ppm}$ and with Aroclor 1254 at $100 \mathrm{ppm}$. These latter results indicate that species differences exist which make it impossible to date to evaluate the possible effect of the high РCB levels that were found in the German Eagles. High PCB levels were reported also in the tissues of Whitetailed Eagles in Sweden (Jensen et al., 1969).

The mercury concentrations found in White-tailed Eagle eggs in Germany are considerably lower than 
those reported by Borg et al. (1969) for Swedish eagles. In five eggs analysed by these authors the levels ranged from 3.5 to $11 \mathrm{ppm}$, whereas in seven of the eggs from Schleswig Holstein the levels were less than $0.5 \mathrm{ppm}$. However, another of these eggs contained $2 \cdot 1 \mathrm{ppm}$. Although this result does not seem to agree with the high concentrations found in the tissues of the dead Eagle, it should be mentioned that this bird could have been a migrant originating from another country, as it was not a member of any of the known breeding pairs of 1969 .

\section{CONCLUSION}

The results of this study provide strong support for the hypothesis that DDE is the main factor responsible for the decline in reproductive success of the population of the White-tailed Eagle in Schleswig Holstein. The decline of reproduction is related to a high rate of embryo mortality, and various experimental studies show clearly that embryo mortality is a characteristic effect of the action of DDE in birds. Further support can be derived from studies on the Bald Eagle in the United States, which demonstrated that high levels of DDE in eggs coincided with a decreased rate of reproduction. The residue levels in most German Eagle eggs approximate those found in Bald Eagle territories where nesting success has been poor for many years.

\section{ACKNOWLEDGEMENTS}

We are indebted to Dr J. J. M. de Goeij and Miss C. Zegers, Interuniversitair . Reactor Institute, Delft, the Netherlands, for their help concerning the mercury analyses. We wish to thank Mr J. H. Pennings for the chemical analysis of samples collected in 1971. Financial support was obtained from the Organization for Applied Sciences (TNO) of the Netherlands and from the World Wildlife Fund.

\section{References}

Borg, K., Wanntorp, H., ERne, K. \& Hanko, E. (1969). Alkyl-mercury poisoning in terrestrial Swedish wildlife. Viltrevy, 6, pp. 301-79.

Borg, K., Erne, K., Hanko, E. \& Wanntorp, H. (1970) Experimental secondary methyl-mercury poisoning in the Goshawk. Environ. Pollut., 1, pp. 91-104.
Coon, N. C., Locke, L. N., Cromartie, E. \& Reichel, W. L. (1970). Causes of Bald Eagle mortality, 1960 1965. J. Wildl. Dis., 6, pp. 72-6.

DeFaubert Maunder, M. J. See Maunder, M. J. DeFAUBERT

HAGEN, W. (1913). Die Vögel des Freistaates und Fürstentums Lübeck. W. Junk, Berlin: $166 \mathrm{pp}$.

Heath, R. G., Spann, J. W. \& Kreitzer, J. F. (1969). Marked DDE impairment of Mallard reproduction in controlled studies Nature, London, 224, pp 47-8.

Heath, R. G., Spann, J. W., Kreitzer, J. F. \& Vance, C. (1970). Effects of polychlorinated biphenyls on birds. Proceedings of $X V$ International Ornithological Congress, The Hague, The Netherlands, 1970 (preprint).

Henriksson, K., Karppanen, E. \& Helminen, M. (1966). High residue of mercury in Finnish White-tailed Eagles. Ornis Fennica, 43, pp. 38-45.

Holden, A. V. \& Marsden, K. (1969). Single-stage cleanup of animal tissue extracts for organochlorine residue analysis. J. Chromatog., 44, pp. 481-92.

Jensen, S., Johnels, A. G., Olsson, M. \& Otterlind, G. (1969). DDT and PCB in marine animals from Swedish waters. Nature, London, 224, pp. 247-50.

Koeman, J. H., GoeiJ, J. J. M. De, Garssen-Hoekstra, J. \& Pels, E. (1971). Poisoning of predatory birds by methyl-mercury compounds. Meded. Rijksfac. Landbouwwetensch. Gent, 36, pp. 43-9.

Kovacs, M. F. (1963). Thin-layer chromatography for pesticide residue analysis. $J$. Assoc. Off. Agric. Chem. 46, pp. 884-93.

Krantz, W. C., Mulhern, B. M., Bagley, G. E., Sprunt IV, A., Ligas, F. J. \& Robertson, W. B. (1970). Organochlorine and heavy metal residues in Bald Eagle eggs. Pesticides Monit. J., 3, pp. 136-40.

Longcore, J. R., SAmson, F. B. \& Whittendale, T. W., Jr. (1971). DDE thins eggshells and lowers reproductive success of captive Black Ducks. Bull. Env. Cont. and Toxicol., 6, pp. 485-90.

Maunder, M. J. DeFaubert, Egan, H., Godly, E. W., Hammond, E. W., Roburn, J. \& Thomson, J. (1964). Clean-up of animal fats and dairy products for the analysis of chlorinated pesticide residues. Analyst, 89, pp. 168-74.

PeaKall, D. B. (1971). Effect of polychlorinated biphenyls (PCBs) on the eggshells of Ring Doves. Bull. Env. Cont. and Toxicol., 6, pp. 100-1.

SPRUNT IV, A. (1963). Bald Eagles aren't producing enough young. Audubon Mag., 65, 32-5.

Stickel, W. H., Stickel, L. F. \& Coon, F. B. (1970). DDE and DDD residues correlated with mortality of experimental birds. Pp. 287-94 in Pesticides Symposia (Ed. W. P. Deichmann). Helios \& Associates, Miami.

Vos, J. G. \& Koeman, J. H. (1970). Comparative toxicological study with polychlorinated biphenyls in chickens with special reference to porphyria, edema formation, liver necrosis, and tissue residues. Toxicol. Appl. Pharmacol., 17, pp. 656-68. 